American Journal of Environmental Sciences 4 (6): 675-682, 2008

ISSN $1553-345 \mathrm{X}$

(C) 2008 Science Publications

\title{
Application of Moving Bed Biofilm Process for Biological Organics and Nutrients Removal from Municipal Wastewater
}

\author{
M. Kermani, B. Bina, H. Movahedian, M.M. Amin and M. Nikaein \\ Department of Environmental Health Engineering, School of Public Health, \\ Isfahan University of Medical Sciences, Isfahan, Iran
}

\begin{abstract}
In this study, experiments have been conducted to evaluate the organics and nutrients removal from synthetic wastewater by a laboratory scale moving bed biofilm process. For nutrients removal, moving bed biofilm process has been applied in series with anaerobic, anoxic and aerobic units in four separate reactors. Moving bed biofilm reactors were operated continuously at different loading rates of nitrogen and Phosphorus. During optimum conditions, close to complete nitrification with average ammonium removal efficiency of $99.72 \%$ occurred in the aerobic reactor. In the aerobic reactor, the average specific nitrification rate was $1.8 \mathrm{~g} \mathrm{NO}_{\mathrm{x}}-\mathrm{N} \mathrm{kg} \mathrm{VSS}^{-1} \mathrm{~h}^{-1}$. The results of the average effluent soluble COD concentration from each reactor showed that denitrification process in the second anoxic reactor consumed most of the biodegradable organic matter. As seen from the results, denitrification rate has increased with increasing $\mathrm{NO}_{\mathrm{x}}-\mathrm{N}$ loading in the second anoxic reactor. The aerobic phosphate removal rate showed a good correlation to the anaerobic phosphate release rate. Moreover, phosphate removal rate showed a strong correlation to the phosphate loading rate in the aerobic reactor. In optimum conditions, the average SCOD, total nitrogen and phosphorus removal efficiencies were 96.9, 84.6 and $95.8 \%$, respectively. This study showed that the moving bed biofilm process could be used as an ideal and efficient option for the total nutrient removal from municipal wastewater.
\end{abstract}

Key words: Bioreactor, biofilm carriers, nitrogen removal, biological phosphorus removal, sewage, treatment

\section{INTRODUCTION}

Limited water resources and increasing urbanization require a more advanced technology to preserve water quality. One of the important factors affecting water quality is the enrichment of nutrients in water bodies ${ }^{[1]}$. Wastewater with high levels of organic matter (COD) Phosphorus (P) and Nitrogen $(\mathrm{N})$ cause several problems, such as eutrophication, oxygen consumption and toxicity, when discharged to the environment ${ }^{[2]}$. It is, therefore, necessary to remove these substances from wastewaters for reducing their harm to environments ${ }^{[3]}$. Biological processes are a cost-effective and environmentally sound alternative to the chemical treatment of wastewater ${ }^{[1]}$. Biological processes based upon suspended biomass (i.e., activated sludge processes) are effective for organic carbon and nutrient removal in municipal wastewater plants. But there are some problems of sludge settleability and the need of large reactors and settling tanks and biomass recycling ${ }^{[4]}$. Biofilm processes have proved to be reliable for organic carbon and nutrients removal without some of the problems of activated sludge processes ${ }^{[5]}$. Biofilm reactors are especially useful when slow growing organisms like nitrifiers have to be kept in a wastewater treatment process. Both nitrification and denitrification have been individually successful in the biofilm reactor ${ }^{[3]}$. There are already many different biofilm systems in use, such as trickling filters, Rotating Biological Contactors (RBCs), fixed media submerged biofilters, granular media biofilters, fluidised bed reactors, etc. They all have advantages and disadvantages.

For these reasons, the moving bed biofilm reactor process (Eur. pat. no. 0575314 , US pat. no. 5,458,779) was developed in Norway in the late 1980s and early $1990 \mathrm{~s}^{[6]}$. The Moving Bed Biofilm Reactor (MBBR) is a highly effective biological treatment process that was developed on the basis of conventional activated sludge process and biofilter process. It is a completely mixed and continuously operated biofilm reactor, where the biomass is grown on small carrier elements that have a

Corresponding Author: M. Kermani, Department of Environmental Health Engineering, School of Public Health, Isfahan University of Medical Sciences, Isfahan, Iran 
little lighter density than water and are kept in movement along with a water stream inside the reactor. The movement inside a reactor can be caused by aeration in an aerobic reactor and by a mechanical stirrer in an anaerobic or anoxic reactor. Researchers have proven that MBBR possesses have many excellent traits such as high biomass, high COD loading, strong tolerance to loading impact, relatively smaller reactor and no sludge bulking problem ${ }^{[7]}$. There are presently more than 400 large-scale wastewater treatment plants based on this process in operation in 22 different countries all over the world ${ }^{[8]}$. During the past decade it has been successfully used for the treatment of many industrial effluents including pulp and paper industry waste $^{[9]}$, poultry processing wastewater ${ }^{[10]}$, cheese factory wastes ${ }^{[1]}$, refinery and slaughter house waste $^{[12]}$, phenolic wastewater ${ }^{[13]}$, dairy wastewater ${ }^{[14]}$ and municipal wastewater ${ }^{[15-22]}$. Moreover, sequencing batch operation of MBBR has been attempted for biological phosphorus removal ${ }^{[4,23]}$, whereas documents and practical experiences with biological nitrogen and phosphorus removal in MBBR process with continuously operation aren't available in Iran and other countries.

The objective of this experimental study was to evaluate organic substances, phosphorus and nitrogen removal by applying a lab-scale MBBR system with continuously operation filled with low cost elements $\left(\right.$ FLOCOR-RMP ${ }^{\circledR}$ ). Using a plastic media easy to produce, low cost and low specific surface $\left(260 \mathrm{~m}^{2}\right.$ $\mathrm{m}^{-3}$ ), the Authors wanted to investigate the lower limit of MBBR profitability.

\section{MATERIALS AND METHODS}

Experimental set-up: The experiments were conducted using four laboratory scale moving bed biofilm reactors in series followed by a final clarifier. No sludge recycle was implemented. The anaerobic reactor $\left(R_{1}\right)$ was constructed for study of Enhanced Biological Phosphorus Removal (EBPR). Because the biological phosphorus removal is initiated in the anaerobic reactor. The first anoxic reactor $\left(R_{2}\right)$ was built to minimize the effect of nitrate in wastewater in entering the anaerobic reactor. One port in the top of $\mathrm{R}_{2}$ allowed for pumping out the anoxic mixed liquor into the anaerobic reactor. The mixed liquor from the first anoxic reactor $\left(R_{2}\right)$ contains substantial soluble COD but little nitrate. Anoxic Recirculation (AR) was provided for increased organic utilization in the anaerobic reactor and optimal conditions for fermentation uptake in the anaerobic reactor. The Anoxic Recirculation (AR) rate was typically 2 times the influent flowrate. The second anoxic reactor $\left(\mathrm{R}_{3}\right)$ followed the first anoxic reactor $\left(R_{2}\right)$ and received Nitrate Recirculation (NR) flow from the aerobic reactor $\left(R_{4}\right)$ to provide the major portion of nitrate removal for the process. The aerobic reactor $\left(R_{4}\right)$ was built to provide the nitrification. One port at the end of the reactor was provided for pumping out the aerobic mixed liquor containing nitrate. Moving bed biofilm reactors placed into a water bath equipped with aquarium heaters in order to operate at the constant temperature of $28 \pm 1^{\circ} \mathrm{C}$. A sketch of the lab-scale moving bed biofilm reactors is shown in Fig. 1 and some key parameters are shown in Table 1. Reactors were operated in an up-flow mode. Sampling ports were provided in each reactor for sample collection. All anaerobic and anoxic reactors had variable speed propellers that pushed the biofilm media downward in the center of reactors. Normal propeller speed was $32 \mathrm{rpm}$. Aerobic reactor equipped with tube diffuser. Air to the aerobic reactor was supplied by an air compressor.

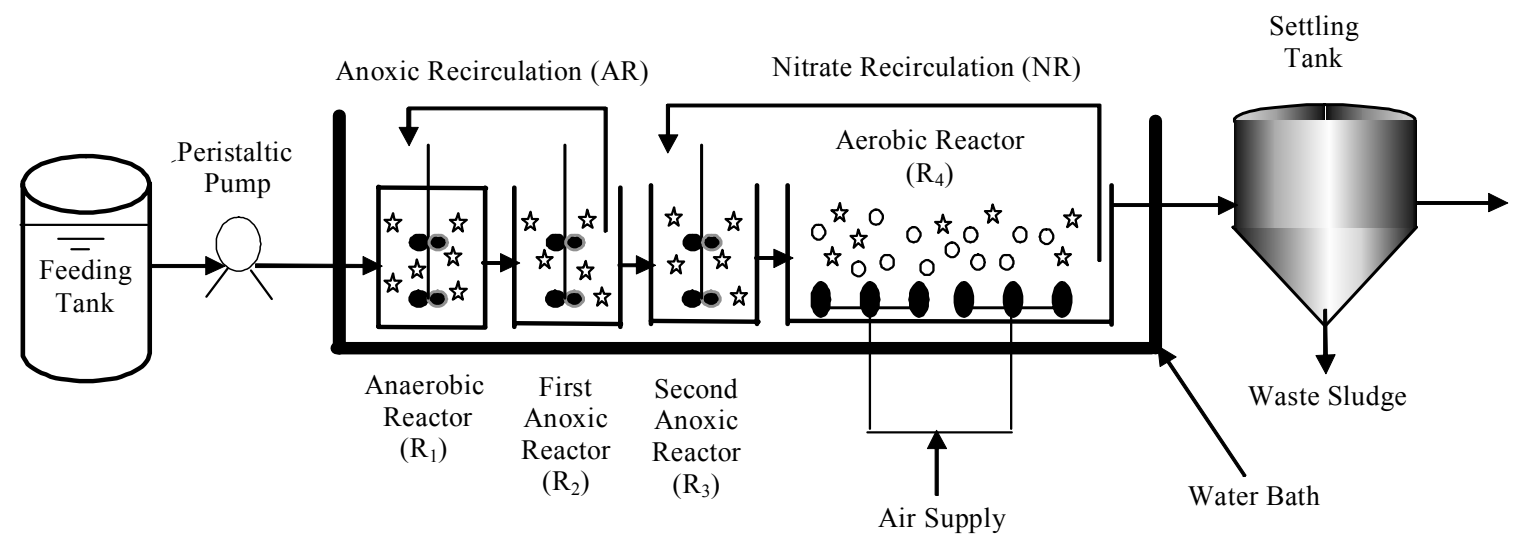

Fig. 1: Schematic diagram of the lab-scale MBBR system 
Am. J. Environ. Sci., 4 (6): 675-682, 2008

Table 1: Technical data for the moving bed biofilm reactors

\begin{tabular}{|c|c|c|c|}
\hline Parameter & Anaerobic reactor $\left(\mathrm{R}_{1}\right)$ & Anoxic reactors $\left(\mathrm{R}_{2}\right.$ and $\left.\mathrm{R}_{3}\right)$ & Aerobic reactor $\left(\mathrm{R}_{4}\right)$ \\
\hline Volume (L) & 3.33 & 3.33 & 10 \\
\hline Filling ratio with bio-carriers (\%) & 50 & 50 & 70 \\
\hline Specific biofilm surface area $\left(\mathrm{m}^{2} \mathrm{~m}^{-3}\right)$ & 130 & 130 & 182 \\
\hline Total biofilm surface area $\left(\mathrm{m}^{2}\right)$ & 0.4329 & 0.4329 & 1.82 \\
\hline Flow rate $\left(\mathrm{L} \mathrm{day}^{-1}\right)$ & 20 & 20 & 20 \\
\hline Flow direction & Up-flow & Up-flow & Up-flow \\
\hline HRT (h) & 4 & 4 & 12 \\
\hline
\end{tabular}

Table 2: Characteristics of the FLOCOR-RMP ${ }^{\circledR}$ plastic media

\begin{tabular}{ll}
\hline Material & Polypropylene \\
\hline Shape & Corrugated cylinder \\
Density & $0.94 \mathrm{~g} \mathrm{~cm}^{-3}$ \\
Dimensions & $10 \times 15 \mathrm{~mm}^{-3}$ \\
Specific surface & $260 \mathrm{~m}^{2} \mathrm{~m}^{-3}$ \\
\hline
\end{tabular}

The airflow to the reactor was measured by a rotameter and regulated with a manual valve. Synthetic wastewater was continuously fed into the bioreactors using a variable speed peristaltic pump (Masterflex L/S pump, Cole-Parmer Instrument Company, USA). Characteristics of the FLOCOR-RMP ${ }^{\circledR}$ plastic media are shown Table 2.

Operating procedure: The study was carried out using synthetic wastewater comprising glucose as the main organic constituent, plus balanced macro and micro nutrients and alkalinity. The wastewater was enriched with the macro-nutrients by adding $\mathrm{NH}_{4} \mathrm{HCO}_{3}$ as nitrogen source and $\mathrm{KH}_{2} \mathrm{PO}_{4}$ and $\mathrm{K}_{2} \mathrm{HPO}_{4}$ as phosphorus sources. The micro-nutrients were added to correct growth conditions for microorganisms according to ${ }^{[24,25]}$. $\mathrm{NaOH}$ and $\mathrm{NaHCO}_{3}$ were used for $\mathrm{pH}$ and alkalinity adjustment. Seeding sludge obtained from Isfahan Municipal Wastewater Treatment Plant was acclimated to the synthetic wastewater prior to the start of the experiments for a few days. The composition of ingredients in prepared wastewater was chosen in a way that the COD concentration of $500 \mathrm{mg} \mathrm{L}^{-1}$ and different concentrations of $\mathrm{NH}_{4}-\mathrm{N}$ ranged from $25-125 \mathrm{mg} \mathrm{L}^{-1}$ and $\mathrm{PO}_{4}-\mathrm{P}$ ranged from 5$25 \mathrm{mg} \mathrm{L}^{-1}$ were prepared and used as feed to the system. The dissolved oxygen concentration in the aerobic reactor ranged from 2.5 to $5.5 \mathrm{mg} \mathrm{L}^{-1}$ depending on the influent organic and ammonium load. Prepared wastewater was continuously pumped into the lab-scale MBBRs with the flow rate of $20 \mathrm{~L} \mathrm{day}^{-1}$. Consequently the theoretical Hydraulic Retention Time (HRT) in the anaerobic/anoxic rectors and in the aerobic reactor was 4 and $12 \mathrm{~h}$, respectively.

Sampling and analysis: Samples were collected from influent and sampling port of each reactor. Temperature, dissolved oxygen and $\mathrm{pH}$ were measured in each reactor every workday, immediately before sampling. All DO and $\mathrm{pH}$ measurements were carried out with an YSI DO meter and $\mathrm{pH}$ meter model CG824 , respectively. The samples were analysed immediately after filtered through $0.45 \mu \mathrm{m}$ filter paper. Soluble COD, ammonium $\left(\mathrm{NH}_{4}-\mathrm{N}\right)$, nitrate $\left(\mathrm{NO}_{3}-\mathrm{N}\right)$, nitrite $\left(\mathrm{NO}_{2}-\mathrm{N}\right)$ and soluble Phosphorus $\left(\mathrm{PO}_{4}-\mathrm{P}\right)$ were measured in accordance with standard methods ${ }^{[26]}$. The assessment of the TSS on the fixed biomass elements was performed as follows: the biofilm was removed from ten plastic elements and diluted in a known amount of demineralized water; after filtration $(0.45 \mu \mathrm{m})$ the sample was dewatered at $105^{\circ} \mathrm{C}$ and weighed; because of the variability of plastic elements dimension, the obtained value was referred to the total measured surface of the ten elements; total suspended solids concentration was assessed through the total surface in a cubic meter of reactor ${ }^{[17]}$.

\section{RESULTS AND DISCUSSION}

Organic carbon removal: The soluble COD removal efficiency variation profile at different reactors of MBBR system is shown in Fig. 2. According to the experiments, the obtained results showed that during optimum conditions $\left(500 \mathrm{mg} \mathrm{COD} \mathrm{L}{ }^{-1}, 62.5 \mathrm{mg} \mathrm{NH}_{4}-\mathrm{N} \mathrm{L}^{-1}\right.$ and $12.5 \mathrm{mg} \mathrm{PO}_{4}-\mathrm{P} \mathrm{L}^{-1}$ ), close to complete organic carbon removal with $96.87 \%$ efficiency occurred in the total MBBR system. As seen from the results, the average soluble COD removal efficiency for the total MBBR system was $95.7 \%$ (Fig. 3). According to Fig. 3, the results of the average effluent soluble COD concentration from each reactor showed that denitrification process in the second anoxic reactor $\left(\mathrm{R}_{3}\right)$, preceding the aerobic reactor $\left(\mathrm{R}_{4}\right)$ in predenitrification system, consumed most of the biodegradable organic matter. Thus, in the aerobic reactor the average biodegradable soluble COD (BSCOD) load was considerably lower and did not interfere with the nitrification. According to ${ }^{[20]}$ degradation of organic matter will slow down or stop the nitrification process. Heterotrophs and nitrifiers will compete for available oxygen and the rapidly growing heterotrophs will dilute (or wash out) the nitrifiers in the biofilm ${ }^{[20]}$. 
Am. J. Environ. Sci., 4 (6): 675-682, 2008

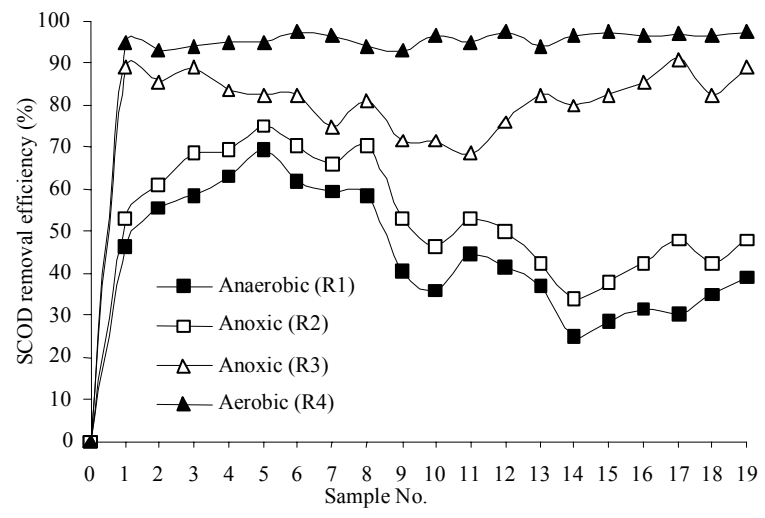

Fig. 2: Soluble COD removal efficiency variation profile at different reactors of MBBR system

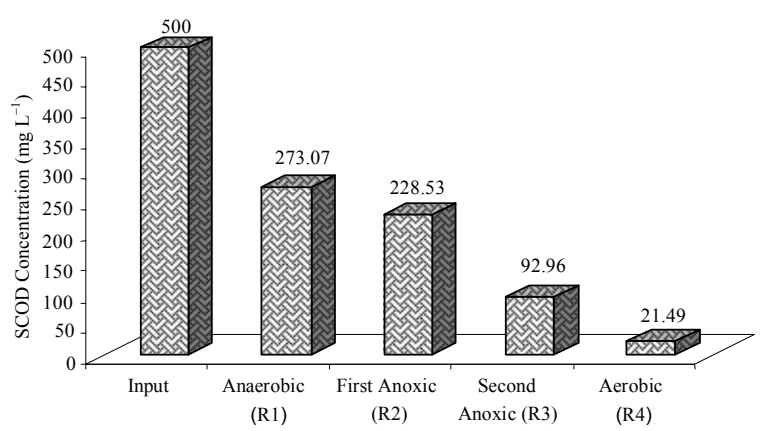

Fig. 3: The average effluent soluble COD concentration from each reactor during experiment

Phosphorus removal: Biological P-removal using enhanced biological phosphorus removal (EBPR) was carried out in this study. In EBPR, phosphorus accumulating organisms $\left(\mathrm{PAO}_{\mathrm{s}}\right)$ are though to play a significant role in phosphorus removal. The first isolated from an enhanced biological phosphorus removal were Acinetobacter species ${ }^{[27]}$. Biological phosphorus removal is initiated in the anaerobic reactor where acetate (and propionate) is taken up by Phosphorus Accumulating Organisms $\left(\mathrm{PAO}_{\mathrm{s}}\right)$ and converted to carbon storage products that provide energy and growth in the subsequent anoxic and aerobic reactors. The phosphorus removal efficiency depended heavily on the operating conditions ${ }^{[28,29]}$. The results indicated that the lab-scale MBBR system has acceptable phosphorus removal efficiency up to $95.76 \%$ in the optimum conditions $\left(500 \mathrm{mg} \mathrm{COD} \mathrm{L}^{-1}\right.$ and 12.5 $\mathrm{mg} \mathrm{PO}_{4}-\mathrm{P} \mathrm{L}^{-1}$ ). As seen from the results, the average phosphorus removal efficiency for the total MBBR system was $87.92 \%$. The results of the average phosphorus removal efficiency in anoxic and aerobic reactors are shown in Fig. 4. In the anoxic reactors,

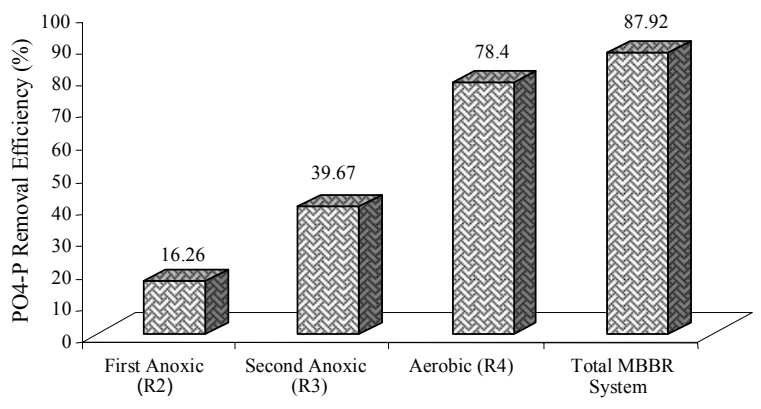

Fig. 4: The average phosphate removal efficiency in anoxic and aerobic reactors during experiment

most $\mathrm{PAO}_{\mathrm{s}}$ can use nitrite in place of oxygen to oxidize their stored carbon source. According to Fig. 4, the maximum phosphorus removal occurred in the aerobic reactor $\left(\mathrm{R}_{4}\right)$. Because under aerobic conditions, energy is produced by the oxidation of storage products and polyphosphate storage within the cell increases. In anoxic and aerobic reactors stored Polyhydroxylbutyrate (PHB) is metabolized and providing energy from oxidation and carbon for new cell growth. The energy released from PHB oxidation is used to form polyphosphate bonds in cell storage so that soluble orthophosphate is removed from solution and incorporated into polyphosphates within the bacteria cell. Cell growth also occurs due to PHB utilization and the new biomass with high polyphosphate storage accounts for phosphorus removal $^{[27]}$. If phosphorus removal efficiency is calculated as aerobic phosphate uptake vs. biomass weight, the average value is $0.814 \mathrm{~g} \mathrm{PO}_{4}-\mathrm{P}$ removed $\mathrm{kg}$ $\mathrm{TSS}^{-1} \mathrm{~h}^{-1}$ or $1.031 \mathrm{~g} \mathrm{PO}_{4} \mathrm{P}$ removed $\mathrm{kg} \mathrm{VSS}^{-1} \mathrm{~h}^{-1}$. According to the Fig. 5, aerobic phosphate removal rate showed a good correlation to the anaerobic phosphate release rate. Anaerobic phosphate release have been calculated based on difference in phosphate concentration at the beginning and end of the anaerobic reactor $\left(\mathrm{R}_{1}\right)$ and the biofilm surface area in this reactor. As indicated, aerobic phosphate removal has increased with increasing anaerobic phosphate release. It should be noted that, COD is the primary source of Volatile Fatty Acids $\left(\mathrm{VFA}_{\mathrm{s}}\right)$ for the phosphorus accumulating organisms. The conversion of COD to $\mathrm{VFA}_{\mathrm{s}}$ occurs quickly through fermentation in the anaerobic reactor. So, the more acetate, the more cell growth and, thus, more phosphorus removal ${ }^{[29]}$. The results suggest that the phosphate removal in aerobic reactor may was inhibited by phosphate release in anaerobic reactor. It should be noted that, the competition between Phosphorus Accumulating Organisms $\left(\mathrm{PAO}_{\mathrm{s}}\right)$ and other heterotrophs, primarily determine the biological 


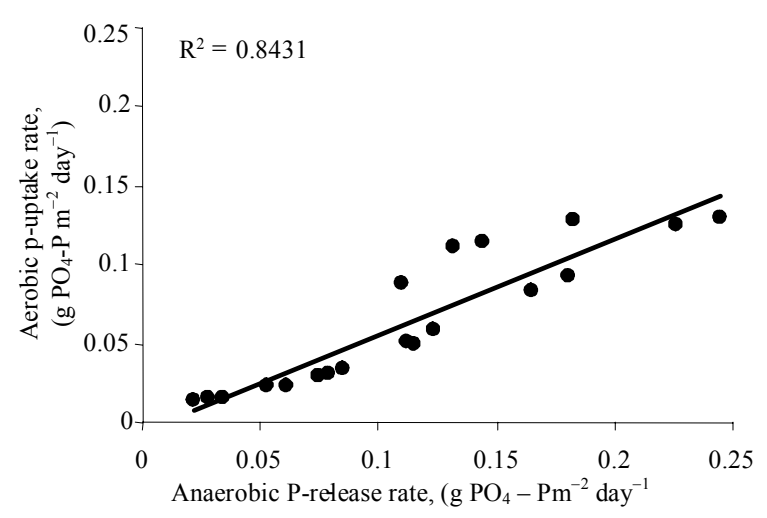

Fig. 5: Aerobic phosphate uptake rate versus anaerobic phosphate release rate in the MBBR system

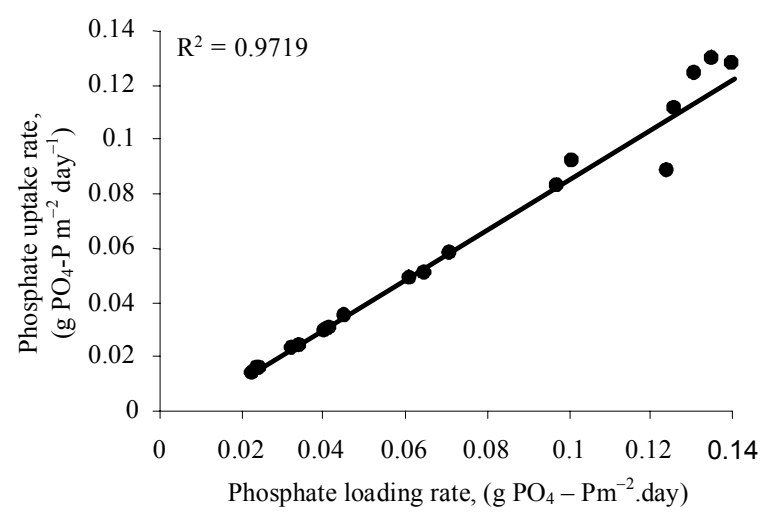

Fig. 6: Phosphate uptake rate versus phosphate loading rate in the aerobic reactor

phosphorus removal. In Fig. 6 a plot of the phosphate removal rate versus the phosphate loading rate in the aerobic rector is shown. According to the results, phosphate removal rate showed a strong correlation to the phosphate loading rate in the aerobic reactor.

Nitrogen removal: Total nitrogen removal in wastewater treatment plants is most commonly and most economically achieved in a two stages system, i.e., nitrification and denitrification. Nitrification transforms ammonia to a more oxidized nitrogen compound such as nitrite or nitrate, which is then converted to nitrogen gas in the subsequent denitrification process ${ }^{[3]}$. This step is followed by the production of Nitric Oxide (NO), nitrous oxide $\left(\mathrm{N}_{2} \mathrm{O}\right)$ and nitrogen gas $\left(\mathrm{N}_{2}\right)$. All three products are gases and can be released into the atmosphere ${ }^{[28,30]}$. Nitrification and denitrification are usually carried out in different reactors because nitrification occurs under aerobic conditions while denitrification prevails in the absence of oxygen ${ }^{[3]}$.

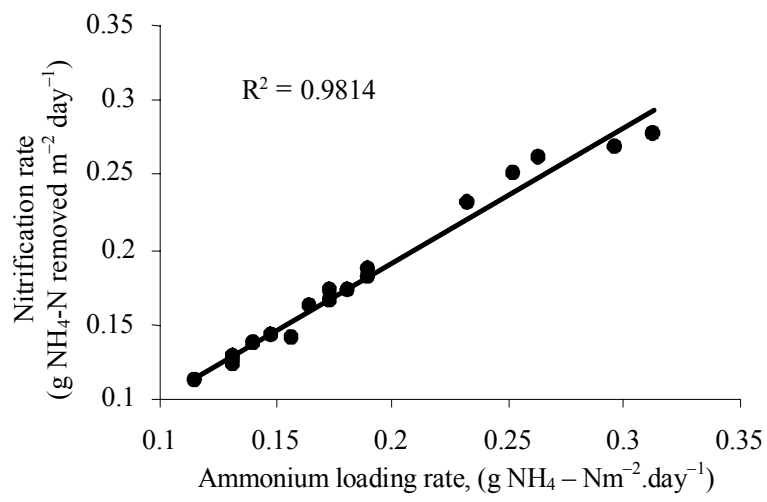

Fig. 7: Nitrification rate versus ammonium loading rate in the aerobic reactor

In general, Nitrosomonas and Nitrobacter are assumed to be responsible for nitrification in wastewaters and denitrification achieved by denitrifying organisms, although an organic carbon source is required ${ }^{[30]}$. Nitrification rates versus ammonium loads are shown in Fig. 7 for the predenitrification MBBR system with nitrate recycling. The data have been calculated based on lab-scale influent and effluent $\mathrm{NH}_{4}-\mathrm{N}$ concentrations and the biofilm surface area in the aerated reactor $\left(\mathrm{R}_{4}\right)$. As indicated, nitrification rate has increased with increasing ammonium loading. The results suggest that the nitrification may was inhibited by substrate (ammonium) concentration so that increasing of the ammonium loading have leaded to increasing the nitrification rate. Normally, the aerobic reactor $\left(\mathrm{R}_{4}\right)$ had very low heterotrophic activity and significantly higher nitrification rates. We have reason to assume that reactor 4 had a biofilm with a thinner layer of heterotrophs and a significantly higher density of nitrifiers. So, excellent $\mathrm{NH}_{4}-\mathrm{N}$ conversion was obtained at overall loads up to $0.3132 \mathrm{~g} \mathrm{NH}_{4}-\mathrm{N} \mathrm{m}^{-2}$ day ${ }^{-1}$, which was the highest load tested. These results demonstrated close to complete $(99.72 \%$ ammonium removal in average) nitrification in aerobic reactor in the optimum conditions (500 mg COD L ${ }^{-1}$ and $62.5 \mathrm{mg} \mathrm{NH}_{4}-\mathrm{N} \mathrm{L}^{-1}$ ). If nitrification rate is calculated as $\mathrm{g} \mathrm{NO}_{\mathrm{x}}-\mathrm{N}$ produced $\mathrm{m}^{-2}$ day $^{-1}$, the average value is $0.1116 \mathrm{~g}^{-2} \mathrm{NO}_{\mathrm{x}}-\mathrm{N}$ produced $\mathrm{m}^{-2} \mathrm{day}^{-1}$. During the experimental work the TSS biofilm concentration was $0.595 \mathrm{~kg} \mathrm{TSS} \mathrm{m}^{-3}$ on the average the VSS/TSS ratio resulted $79 \%$. Thus the average specific nitrification rate in the aerobic rector can be expressed as $1.8 \mathrm{~g} \mathrm{NO}_{\mathrm{x}}-\mathrm{N} \mathrm{kg} \mathrm{VSS}{ }^{-1} \mathrm{~h}^{-1}(1.422 \mathrm{~g}$ $\mathrm{NO}_{\mathrm{x}}-\mathrm{N}$ kg TSS${ }^{-1} \mathrm{~h}^{-1}$ ). Andreottola et al. ${ }^{[16]}$ observed an average nitrification rate as $1.84 \mathrm{~g} \mathrm{NO}_{3}-\mathrm{N} \mathrm{kg}$ $\mathrm{VSS}^{-1} \mathrm{~h}^{-1[17]}$. Three factors, the load of organic matter, the ammonium concentration and the oxygen 
Am. J. Environ. Sci., 4 (6): 675-682, 2008

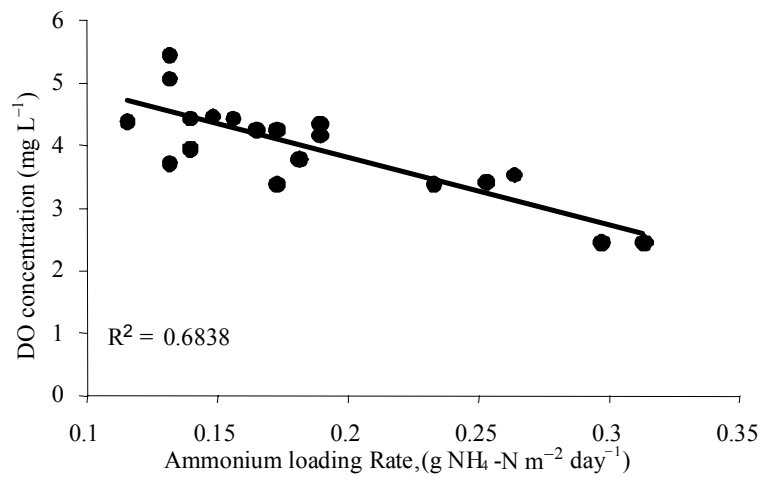

Fig. 8: Dissolved oxygen concentration versus ammonium loading rate in the aerobic reactor

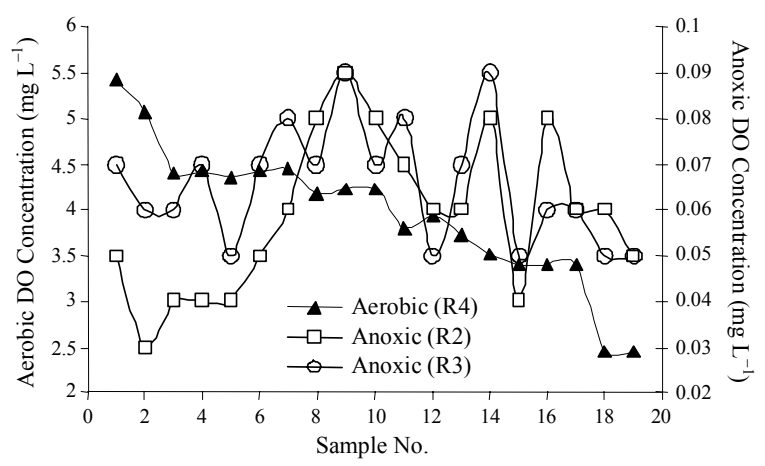

Fig. 9: DO variation profile at the anoxic and aerobic reactors

concentration, primarily determine the nitrification rate. Organic load controls nitrification and should be as low as possible. Nitrification rates will depend on the mixture and distribution heterotrophs and nitrifiers within the biofilm and the oxygen penetration into the biofilm $^{[20]}$. The relationship between Dissolved Oxygen concentrations and ammonium loading rates in the aerobic reactor are shown in Fig. 8. Oxygen or ammonia may be the rate-limiting substrate for nitrification. DO variation profile at the anoxic and aerobic reactors was demonstrated in Fig. 9. As indicated, Do concentration in the aerobic reactor has decreased with increasing ammonium loading rate (different concentration of $\mathrm{NH}_{4}-\mathrm{N}$ from 25-125 $\mathrm{mg} \mathrm{L}^{-1}$ ). According to Hem et al., ${ }^{[25]}$ to get nitrification, the DO level in the aerated reactor must be sufficiently high to penetrate through the outer layer of oxygen consuming heterotrophs and into the nitrifying bacteria. The nitrification rate is found to be close to linearly dependent upon the oxygen concentration, up to more than $10 \mathrm{mg} \mathrm{O}_{2} \mathrm{~L}^{-1}$. Also, he showed that liquid film diffusion was an important parameter for the moving

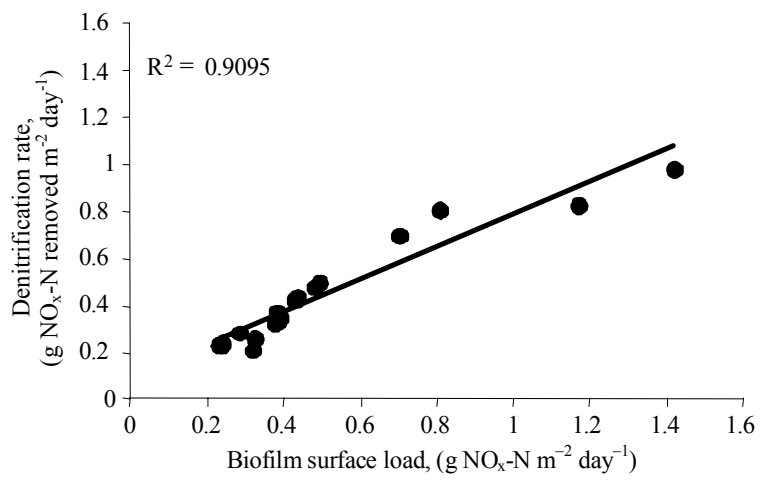

Fig. 10: Denitrification rate versus $\mathrm{NO}_{\mathrm{x}}-\mathrm{N}$ loading rate in the anoxic reactor

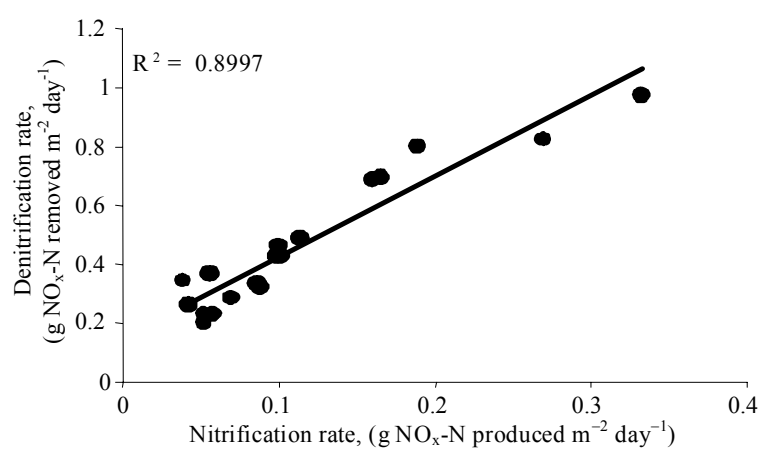

Fig. 11: Denitrification rate versus nitrification rate in the MBBR system

biofilm reactors ${ }^{[25]}$. Figure 10 shows denitrification rates versus $\mathrm{NO}_{\mathrm{x}}-\mathrm{N}$ loads $\left(\mathrm{NO}_{\mathrm{x}}-\mathrm{N}=\mathrm{NO}_{2}-\mathrm{N}+\mathrm{NO}_{3}-\mathrm{N}\right)$ for the second anoxic reactor $\left(\mathrm{R}_{3}\right)$. The data have been calculated based on lab-scale influent and effluent $\mathrm{NO}_{\mathrm{x}^{-}}$ $\mathrm{N}$ concentrations and the biofilm surface area in the second anoxic reactor $\left(\mathrm{R}_{3}\right)$. As indicated, the denitrification rate has increased with increasing $\mathrm{NO}_{x}-\mathrm{N}$ loading. As shown in Fig. 10, the maximum denitrification rate was $0.978 \mathrm{~g} \mathrm{NO}_{\mathrm{x}}-\mathrm{N}$ removed $\mathrm{m}^{-2}$ day $^{-1}$. The denitrification rate may be limited by the nitrate concentration, the biodegradable organic matter concentration or by the oxygen concentration (or rather the presence of oxygen). If oxygen is supplied to the reactor with the inlet wastewater or recirculated wastewater, biodegradable organic matter will be consumed for oxygen respiration and thus reduce the available amount for denitrification. Nitrification is a prerequisite for denitrification. Figure 11 shows denitrification rate versus nitrification rate in the labscale MBBR system. Figure 11 shows a linear relation between nitrification rate and denitrification rate. Finally, the results indicated that the lab-scale MBBR 
system has acceptable total nitrogen removal efficiency up to $84.6 \%$ in the optimum conditions (500 $\mathrm{mg}$ COD $\mathrm{L}^{-1}$ and $62.5 \mathrm{mg} \mathrm{NH}_{4}-\mathrm{N} \mathrm{L}^{-1}$ ).

\section{CONCLUSION}

In this research an experimental study to evaluate the application of MBBR system for the organic carbon and nutrients removal from wastewater is described. Based on the experimental results obtained from the lab-scale MBBR process behavior, the following conclusions can be made:

- The results of the average effluent soluble COD concentration from each reactor showed that denitrification process in the second anoxic reactor consumed most of the biodegradable organic matter

- Aerobic phosphate removal rate showed a good correlation to the anaerobic phosphate release rate

- During optimum conditions, close to complete nitrification occurred in the aerobic reactor with average ammonium removal efficiency of $99.72 \%$

- In the aerobic reactor, the average specific nitrification rate was $1.8 \mathrm{~g} \mathrm{NO}_{\mathrm{x}}-\mathrm{N} \mathrm{kg} \mathrm{VSS}{ }^{-1} \mathrm{~h}^{-1}$ (1.422 $\mathrm{g} \mathrm{NO}_{\mathrm{x}}-\mathrm{N} \mathrm{kg} \mathrm{TSS}^{-1} \mathrm{~h}^{-1}$ )

- Denitrification rate has increased with increasing $\mathrm{NO}_{\mathrm{x}}-\mathrm{N}$ loading in the second anoxic reactor and the maximum denitrification rate was $0.978 \mathrm{~g} \mathrm{NO}_{\mathrm{x}^{-}}$ $\mathrm{N}$ removed $\mathrm{m}^{-2}$ day $^{-1}$

- In overall, the lab-scale MBBR system was a very effective process for close to complete organics and nutrients removal, with average soluble COD, total nitrogen and phosphorus removal efficiencies of $96.9,84.6$ and $95.8 \%$, respectively, during optimum conditions

- According to the results, we suggest that the moving bed biofilm process could be used as an ideal and efficient option for the total nutrient removal from municipal wastewater

\section{ACKNOWLEDGMENT}

The authors would like to express their thanks to the laboratory's staff of the Department of Environmental Health Engineering, School of Public Health, for their collaboration and also to the research administration of Isfahan University of Medical Sciences for the financial and administrative supports under grant Number 385362 . The authors gratefully acknowledge the contribution of Mr. Farrokhzadeh for his work to build the lab-scale MBBR system.

\section{REFERENCES}

1. Mulkerrins, D., A.D.W. Dobson and E. Colleran, 2004. Parameters affecting biological phosphate removal from wastewaters. Environ. Inter., 30: 249-259. DOI: 10.1016/S0160-4120(03)00177-6.

2. Luostarinen, S., S. Luste, L. Valentin and J. Rintala, 2006. Nitrogen removal from on-site treated anaerobic effluents using intermittently aerated moving bed biofilm reactors at low temperatures. Water Res., 40: 1607-1615. DOI: 10.1016/j.watres.2006.02.022.

3. Wang, X.J., S.Q. Xia, L. Chen, J.F. Zhao, N.J. Renault and J.M. Chovelon, 2006. Nutrients removal from municipal wastewater by chemical precipitation in a moving bed biofilm reactor. Process Biochem., 41: 824-828. DOI: 10.1016/j.procbio.2005.10.015.

4. Pastorelli, G., R. Canziani, L. Pedrazzi and A. Rozzi, 1999. Phosphorus and nitrogen removal in moving-bed sequencing batch biofilm reactors. Water Sci. Technol., 40: 169-176. http://lequia. udg.es/lequianet/WatSciTech/04004/0169/0400401 69.pdf.

5. Ødegaard, H., B. Rusten and T. Westrum, 1994. A new moving bed biofilm reactor-applications and results. Water Sci. Technol., 29: 157-165. http://www.iwaponline.com/wst/02910/wst029100 157.htm.

6. Ødegaard, H., 2006. Innovations in wastewater treatment: the moving bed biofilm process. Water Sci. Technol., 53: 17-33. http://www. iwaponline.com/wst/05309/wst053090017.htm.

7. Chen, S., D. Sun and J.S. Chung, 2008. Simultaneous removal of COD and ammonium from landfill leachate using an anaerobic-aerobic moving-bed biofilm reactor system. Waste Manage., 28: 339-346. DOI:10.1016/j.wasman. 2007.01.004.

8. Rusten, B., B. Eikebrokk, Y. Ulgenes and E. Lygren, 2006. Design and operations of the Kaldnes moving bed biofilm reactors. Aquacult. Eng., 34 : 322-331. DOI: 10.1016/j.aquaeng.2005.04.002.

9. Jahren, S.J., J.A. Rintala and H. Ødegaard, 2002. Aerobic moving bed biofilm reactor treating thermomechanical pulping whitewater under thermophilic conditions. Water Res., 36: $\quad 1067-1075 . \quad$ DOI: $10.1016 /$ S00431354(01)00311-6.

10. Rusten, B., J.G. Siljudalen, A. Wien and D. Eidem, 1998. Biological pretreatment of poultry processing wastewater. Water Sci. Technol., 38: 19-28. DOI: 10.1016/S0273-1223(98)00493-4. 
11. Rusten, B., J.G. Siljudalen and H. Strand, 1996. Upgrading of a biological-chemical treatment plant for cheese factory wastewater. Water Sci. Technol., 34: 41-49. DOI: 10.1016/S0273-1223(96)00819-0.

12. Johnson, C.H., M.W. Page and L. Blaha, 2000. Full scale moving bed biofilm reactor results from refinery and slaughter house treatment facilities. Water Sci. Technol., 41: 401-407. http://www. iwaponline.com/wst/04104/wst041040401.htm.

13. Hosseini, S.H. and S.M. Borghei, 2005. The treatment of phenolic wastewater using a moving bed bio-reactor. Process Biochem., 40: 1027-1031. DOI: 10.1016/j.procbio.2004.05.002.

14. Andreottola, G., P. Foladori, M. Ragazzi and R. Villa, 2002. Dairy wastewater treatment in a moving bed biofilm reactor. Water Sci. Technol., 45: 321-328. http://www.iwaponline.com/wst/ 04512/wst045120321.htm.

15. Andreottola, G., P. Foladori, G. Gatti, P. Nardelli, M. Pettena and M. Ragazzi, 2003. Upgrading of a Small Overloaded Activated Sludge Plant Using a MBBR System. J. Environ. Sci. Health, Part A, 38: 2317-2328. http://www.informaworld.com/ smpp/content $\sim \mathrm{db}=$ all? content $=10.1081 /$ ESE120023388 .

16. Andreottola, G., P. Foladori, M. Ragazzi and F. Tatano, 2000. Experimental comparison between MBBR and activated sludge system for the treatment of municipal wastewater. Water Sci. Technol., 41: 375-382. http://www.iwaponline. com/wst/04104/wst041040375.htm.

17. Andreottola, G., P. Foladori and M. Ragazzi, 2000. Upgrading of a small wastewater treatment plant in a cold climate region using a moving bed biofilm reactor (MBBR) system. Water Sci. Technol., 41: 177-185. http://www.iwaponline.com/wst/ 04101/wst041010177.htm.

18. Rusten, B., M. McCoy, R. Proctor and J.G. Siljudalen, 1998. The innovative moving bed biofilm reactor/solids contact reaeration process for secondary treatment of municipal wastewater. Water Environ. Res., 70: 1083-1089. http://www.ingentaconnect.com/content/wef/wer/1 998/00000070/00000005/art00015.

19. Rusten, B., O. Kolkinn and H. Ødegaard, 1997. Moving bed biofilm reactors and chemical precipitation for high efficiency treatment of wastewater from small communities. Water Sci. Technol., 35: 71-79. DOI: 10.1016/S02731223(97)00097-8.

20. Rusten, B., L. Hem and H. Ødegaard, 1995. Nitrification of municipal wastewater in novel moving bed biofilm reactors. Water Environ. Res., 67: 75-86. http://www.ingentaconnect.com/content/ wef/wer/1995/00000067/00000001/art00009.
21. Rusten, B., L. Hem and H. Ødegaard, 1995. Nitrogen removal from dilute wastewater in cold climate using moving bed biofilm reactors. Water Environ. Res., 67: 65-74. http://www. ingentaconnect.com/content/wef/wer/1995/000000 67/00000001/art00008.

22. Rusten, B., J.G. Siljudalen and B. Nordeidet, 1994. Upgrading to nitrogen removal with the KMT moving bed biofilm process. Water Sci. Technol., 29: 185-195. http://www.iwaponline.com/wst/ 02912/wst029120185.htm.

23. Helness, H. and H. Ødegaard, 1999. Biological Phosphorus Removal in a Sequencing Batch Moving Bed Biofilm Reactor. Water Sci. Technol., 40: 161-168. http://www.iwaponline.com/wst/ 04004/wst040040161.htm.

24. Dulkadiroglu, H., E.U. Cokgor, N. Artan and D. Orhon, 2005. The effect of temperature and sludge age on COD removal and nitrification in a moving bed sequencing batch biofilm reactor. Water Sci. Technol., 51: 95-103. http://www. iwaponline. com/wst/05111/wst051110095.htm.

25. Hem, L.J., B. Rusten. And H. Ødegaard, 1994. Nitrification in a moving bed biofilm reactor. Water Sci. Technol., 28: 1425-1433. DOI: 10.1016/0043-1354(94)90310-7.

26. APHA, AWWA and WEF, 1999. Standard Methods for the Examination of Water and Wastewater. 20th Edn., American Public Health Association, Washington DC. ISBN: 0875532357.

27. Okunuki, S., M. Kawaharasaki, H. Tanaka and T. Kanagawa, 2004, Changes in phosphorus removing performance and bacterial community structure in an enhanced biological phosphorus removal reactor. Water Res., 38: 2433-2439. DOI: 10.1016/j.watres.2004.02.008.

28. Tchobanoglous, G., F.L. Burton and H.D. Stensel, 2003. Wastewater Engineering, Treatment and Reuse. 4th Edn., McGraw Hill, New York. ISBN: 0-07-041878-0.

29. Chuang, S.H., C.F. Ouyang, H.C. Yuang and S.J. You, 1998, Evaluation of phosphorus removal in anaerobic anoxic aerobic system-via polyhydroxyalkonoates measurements. Water Sci. Technol., 38: 107-114. DOI: 10.1016/S02731223(98)00472-7.

30. Sedlak, R., 1991. Phosphorus and Nitrogen Removal from Municipal Wastewater: Principles and Practice. 2nd Edn., Lewis Publishers, New York. ISBN: 0-87371-683-3. 